\title{
Writing Materials
}

\section{Writing Surfaces}

The material support on which writing is done plays an important role in the writing process and therefore constitutes an essential part of the history of documents. From the conservation point of view, the interaction between the support and the ink is of paramount importance. In this work, I will investigate possible correlations between the use of specific supports or writing surfaces and specific inks and try to assess whether it is possible to see a combination of ink and writing support that would serve as a marker of a specific social or religious group or would be characteristic of a single scribe or date.

The writing materials found in the Genizah include papyrus and paper, leather and parchment, and even textiles. However, the documents considered in this study were written only on paper, parchment and leather, and we will therefore limit our description to these materials. The lion's share of the 391 manuscripts presented in this work was written on paper (257) followed by parchment (113). Only a small number of manuscripts - all of them nonbiblical scrolls of religious content from the Babylonian community ${ }^{1}$ - were written on leather, clearly indicating its specific use.

\subsection{Skin-based Materials: Leather and Parchment}

In general, parchment is a writing material made from animal hides, as is leather. Historically, parchment for writing was predominantly produced from sheep, goat and cattle, with the choice of animal depended on geographical region and date.

Since the Middle Ages, production of parchment has consisted of three main steps: de-hairing with the help of lime solution, drying under tension and finishing. ${ }^{2}$ De-hairing is the only production step common to both leather and parchment. Starting from the second step, the treatment becomes

1 None of the analysed scrolls were Torah scrolls.

2 Michael Gullick, 'From Parchmenter to Scribe: Some Observations on the Manufacture and Preparation of Medieval Parchment Based upon a Review of the Literary Evidence, in Pergament: Geschichte, Struktur, Restaurierung, Herstellung, ed. Peter Rück, Historische Hilfswissenschaften (Sigmaringen: Jan Thorbecke, 1991), 145-57; Michael L. Ryder, 'The Biology and History of Parchment', in Pergament: Geschichte, Struktur, Restaurierung, Herstellung, ed. Peter Rück, Historische Hilfswissenschaften (Sigmaringen: Jan Thorbecke, 
dramatically different. To make leather, a de-haired and washed hide is placed in a tannin ${ }^{3}$ solution (or tanned in some other way) whereas for parchment production the hide is dried under tension, being stretched on a frame, thinned and cleaned until it is transformed into a rigid white sheet. In the final step, parchment is smoothed and polished. Though this basic recipe has not changed over centuries, individual and local refinements resulted in writing materials of different qualities and colours. The best writing parchment is made of dermis, whose hair and flesh sides show no difference to the naked eye. Usually, however, these two sides are easily recognisable both in leather and in parchment of lesser quality. Accordingly, the colour of parchment can range from snow-white to ivory. ${ }^{4}$

As noted, generally speaking, one of the major differences between leather and parchment is tanning, at least outside the Jewish world. ${ }^{5}$ In contrast to leather, parchment is not normally tanned in order to become a suitable writing surface. ${ }^{6}$ The main exceptions known are the parchments of the Dead Sea Scrolls produced in Antiquity and Jewish medieval parchments that were allegedly tanned before sacred texts were inscribed on them. ${ }^{7}$

Studies of the skin-based material of the Dead Sea Scrolls have also revealed that there were different de-hairing techniques in Antiquity in contrast with the single technique of the Middle Ages. ${ }^{8}$ In one of the techniques, depilation

1991), 25-33; Ronald Reed, The Nature and Making of Parchment, ed. A. S. Maney, First Edition (Leeds: Elmete Press, 1975).

3 Tannins are a group of polyphenolic compounds of vegetable origin capable of precipitating proteins. Tannins have been traditionally used to convert hides to leather, which process is called tanning (Ann E. Hagerman, The Tannin Handbook (Miami: University Oxford, 2011), http://www.users.miamioh.edu/hagermae/.). For the use of tannins in leather production see Ronald Reed, Ancient Skins, Parchments and Leathers (London: Seminar Press, 1972), $72-84$.

4 Reed, Ancient Skins, Parchments and Leathers, 63.

5 As explained, the difference of preparation between leather and parchment is in stretching and not in tanning. However, here we are very interested in the tanned property because tanned parchment is a specificity found mostly in the Jewish world. Furthermore, our equipment is able to detect the use or absence of tannins.

6 We will see in 3.1.2 that the colour of the document is not a criterion for discrimination between leather and parchment, and that the study of the writing surface through uv light is needed to assess whether tannin has been used or not.

7 John B Poole and Ronald Reed, 'The Preparation of Leather and Parchment by the Dead Sea Scrolls Community', Technology and Culture 3 (1962): 17-18, https://doi.org/10.2307/3100798., quoting Maimonides, Mishneh Torah, chap. I, 6-9 Laws concerning Phylacteries, the Mezuzah and the Scroll of the Law.

8 Poole and Reed, 'The Preparation of Leather and Parchment by the Dead Sea Scrolls Community', 17-18. quoting Maimonides, Mishneh Torah, chap. I, 6-9 Laws concerning Phylacteries, the Mezuzah and the Scroll of the Law. 
of the hides was conducted using sulfur salts that resulted in milky white parchments. These types of parchment were either not tanned or tanned very lightly on the surface. The second technique involved de-hairing with the help of vegetable matter. In these cases, the resulting parchment was usually tanned, meaning that it is not possible to clarify whether tannins were already present in the de-hairing mixture. This type of parchment is, in fact, a hybrid between parchment (since it was dried under tension) and leather (the tanning was quite considerable). It has been proposed that the two different techniques originated from different geographical regions: the pale parchments were associated with the West (i.e. Hellenistic Greece) and were the predecessors of the medieval European parchment, while the brown parchment was related to the working of hides in the East (i.e. the area corresponding to the Seleucid empire).$^{9}$

It is very interesting that only Babylonian scrolls in this study have been found to be written on leather, whereas the scrolls of the Palestinian community are always on untanned parchments. ${ }^{10}$ This corresponds well to the fact that only the Babylonian Talmud requires tanning before sacred texts are inscribed. ${ }^{11}$

\subsection{Paper}

In the most general way, paper can be described as a thin flat material produced from various plant fibres through a process of depleting water from an aqueous fibre pulp suspension by placing this in a sieve-like mould. The initial stage of paper production - the beating of the raw material into fibres to produce a pulp - has not changed significantly from the time of its invention in the 2nd century вСE in China during the Han dynasty. It has been claimed that paper technology entered the Islamic world after the defeat of the Tang forces in the Battle of Talas against the Abbasid caliphate in $75^{1} \mathrm{CE}$,

$9 \quad$ Ira Rabin and Oliver Hahn, 'Characterization of the Dead Sea Scrolls by Advanced Analytical Techniques', Analytical Methods 5, no. 18 (2013): 4648-54, https://doi.org/10.1039/ сзау41076e.

10 The scrolls studied here have been already described and studied in Olszowy-Schlanger, 'The Anatomy of Non-Biblical Scrolls from the Cairo Geniza'. However, at the time of this publication, no thourough study of the inks was made, which is one of the aspects we are offering ourselves to do here.

11 Menahem Haran, 'Technological Heritage in the Preparation of Skins for Biblical Texts in Medieval Oriental Jewry', in Pergament: Geschichte, Struktur, Restaurierung, Herstellung, ed. Peter Rück, Historische Hilfswissenschaften (Sigmaringen: Jan Thorbecke, 1991), 35; Rabin, 'Building a Bridge', 311-13. 
when several Chinese papermakers fell in captivity. ${ }^{12}$ It seems, however, that paper was known before this battle as an rare and exceptional imported good. ${ }^{13}$ According to Karabacek, the start of paper production in Baghdad can be dated to $795 \cdot{ }^{14}$ From the Islamic world, papermaking moved further west and reached Europe, where it has been produced since the 12th century.

The geographical spread of papermaking and technological progress affected the choice of raw materials and the way in which it was treated following the drying of the primary paper sheets, and indeed even the way the drying process itself was carried out. Today, we distinguish between historical Oriental, Islamic, European and industrial paper: it is Islamic paper of the 11th century that interests us in this work. In the first centuries of papermaking, textile rags were used as the raw material. They were pounded into a pulp, which was then placed on a sieve screen, drained of water and dried. In addition to rags, plants like flax could also be used directly. According to Ibn Bādis, whose early medieval treatise was translated and published in the Western world by Levey, ${ }^{15}$ in order to produce paper, flax was soaked in quicklime, rubbed and spread in the sun to dry. The resulting fibres were then washed several times to remove the quicklime, pounded into pulp, washed again, shaped into moulds and dried. ${ }^{16}$

To prepare paper for writing, one had to size and polish it in order to suppress the uncontrolled penetration and spread of the ink. Sizing refers to dipping the primary paper into a glue suspension or applying such a suspension to the paper with the help of brushes. ${ }^{17}$ According to Bloom, ${ }^{18}$ rice starch

12 Peter F. Tschudin, 'Conférence Inaugurale. Le Développement Technique de La Papeterie, de Ses Débuts En Asie à l'Europe de La Renaissance', in Le Papier Au Moyen-Âge: Histoire et Techniques, ed. Monique Zerdoun Bat-Yehuda, vol. 19 (Turnhout: Brepols Publishers, 1999), 9, https://doi.org/10.1484/M.BIB-EB.3.4839; Jonathan M. Bloom, Paper before Print: The History and Impact of Paper in the Islamic World (New Haven: Yale University Press, 2001), 42-43.

13 Geneviève Humbert, 'Le Manuscrit Arabe et Ses Papiers', Revue Des Mondes Musulmans et de La Méditerranée, no. 99-100 (2002): 58.

14 Joseph von Karabacek, Don Baker, and Suzy Dittmar, Arab Paper (London: Archetype Publications Ltd, 2001), 33 .

15 Levey, 'Mediaeval Arabic Bookmaking and Its Relation to Early Chemistry and Pharmacology', 39-41.

16 Levey, 10.

17 Colini, 'From Recipes to Material Analysis the Arabic Tradition of Black Inks and Paper Coatings (9th-2oth Century)', 15 .

18 Jonathan M. Bloom, 'Papermaking: The Historical Diffusion of an Ancient Technique', in Mobilities of Knowledge, ed. Heike Jöns, Peter Meusburger, and Michael Heffernan, vol. 10, Knowledge and Space (Cham: Springer International Publishing, 2017), 62, https://doi .org/10.1007/978-3-319-44654-7_3. 
was most commonly used for this because wheat starch, besides being difficult to produce, had a bad smell. Burnishers of stone, wood or bone could be used in the polishing process.

In the Cairo Genizah, the earliest example of a document written on paper is T-S $16.181,{ }^{19}$ dated to $933 .{ }^{20}$ However, paper seems to have been used commonly in Fusțât only from the early 11 th century. ${ }^{21}$ In 1064, Nasir-i Khosrau, wrote that, in Cairo, grocers were giving paper to their clients in which to wrap their groceries, ${ }^{22}$ indicating that cheap paper was available at that time.

A study of 21 paper manuscripts from the Cairo Genizah has shown that, based on the state of preservation of the fibres, the paper was produced from secondary raw materials such as rags. Those manuscripts, preserved today in the collection of the library of the Jewish Theological Seminary, were written in the Land of Israel during the 11th and 12th centuries. With the help of microscopy, the researchers found cotton, flax fibres and some wool from the rags. ${ }^{23}$ The predominance of cotton fibres is of particular interest since cotton was less common than linen or hemp and grew only in the eastern part of the Islamic empire; ${ }^{24}$ one might tentatively suggest that the paper was produced there. Interestingly, no starch was detected on the surface of any of these documents. Another study on paper from the Genizah, conducted by Baker, has confirmed that some paper produced during the second half of the 11th century was not sized with starch; but that other paper was. ${ }^{25}$ Baker was unable

19 Olszowy-Schlanger, 'Manuscrits hébreux et judéo-arabes: Paléographie des documents juridiques de Fustat du Xe siècle.', 29.

20 It is quite likely that there are earlier undated documents written on paper.

21 Olszowy-Schlanger, 'Manuscrits hébreux et judéo-arabes: Paléographie des documents juridiques de Fustat du Xe siècle.', 29.

22 Humbert, 'Le Manuscrit Arabe et Ses Papiers', 63; 1003-1088 Nasir-i Khusraw, Sefer nameh; relation du voyage de Nassiri Khosrau en Syrie, en Palestine, en Égypte, en Arabie et en Perse, pendant les années de l'Hégire 437-444 (1035-1042), ed. and trans. Charles Schefer (Paris: Ernest Leroux, 1881), 153, http://archive.org/details/sefernamehrelationnasiuoft.

23 Zohar Amar, Azriel Gorski, and Izhar Neumann, 'Raw Materials in the Paper and Textile Industry in Al-Sham during the Middle Ages in Light of an Analysis of Documents from the Cairo Genizah', in IPH Congress Book, vol. 15, 2004, 39-44; Zohar Amar, Azriel Gorski, and Izhar Neumann, 'The Paper And Textile Industry In The Land Of Israel And Its Raw Materials In Light Of An Analysis Of The Cairo Genizah Documents', in From a Sacred Source, Études Sur Le Judaïsme Médiéval 42 (Leiden: Brill, 2011), 25-42, https://doi.org/ 10.1163/ej.978900419058o.i-420.11.

24 Amar, Gorski, and Neumann, 'Raw Materials in the Paper and Textile Industry in Al-Sham during the Middle Ages in Light of an Analysis of Documents from the Cairo Genizah'; Bloom, 'Papermaking', 58 .

25 Don Baker, 'Arab Paper Making', The Paper Conservator 15, no. 1 (1991): 31, https://doi.org/10 .1080/03094227.1991.9638394. 
to determine the reason for this difference: either the starch on the surface has degraded to the point that it has disappeared, or no starch at all was used to size the paper.

The most common ink used in the Cairo Genizah is black ink - although the category of black ink includes what are now "brown inks", since the current appearance of an ink can result from ageing, degradation and restoration. Black inks in the medieval Islamic world can be divided in four distinguishable categories: inks based on soot or charcoal (carbon), those based on plant material, those based on iron-gall, and mixed inks. The first of these is a fine dispersion of carbon pigments in a water-soluble binding agent; plant inks, said to have been commonly used in the Middle Ages, are made on the basis of tannins contained in tree bark or gallnuts; iron-gall ink is based on the black pigment produced from the reaction between iron(II) and gallic acid, which is found in gallnuts, for example; while mixed inks are writing fluids resulting from the intentional mixing of carbon ink with plant or iron-gall ink.

\subsection{Carbon Ink}

Carbon ink is believed to be the oldest type of black ink. ${ }^{26}$ The basic recipe involves soot or pulverised charcoal being mixed with a water-soluble binding medium such as gum arabic (which was used in Egypt) or protein glue (used in China). The resulting paste was pressed into small bars similar to the ones commercially available today as Indian ink. To write with it, the dry ink was mixed with water to produce a suitable fluid, whose viscosity depended on the writing tool to be used. Carbon ink does not penetrate the writing support and resides on its surface so that it can be easily scraped off. ${ }^{27}$

Among the oldest extant recipes of carbon ink, the one recorded by Pliny the Elder in his Natural History is the best known; ${ }^{28}$ the recipe of Dioscorides from the 1st century $\mathrm{BCE}$, which suggests adding a copper compound to the

26 Alfred Lucas, 'The Inks of Ancient and Modern Egypt', Analyst 47, no. 550 (1922): 10; Pierre Tallet, 'Ayn Sukhna and Wadi El-Jarf: Two Newly Discovered Pharaonic Harbours on the Suez Gulf', British Museum Studies in Ancient Egypt and Sudan 18 (2012): 147-68; Paul T. Nicholson and Ian Shaw, 'Ancient Egyptian Materials and Technology', 2000, 238.

27 However, we would like to soften this statement by pointing out that in the case of unsized paper the ink will soak through the writing surface.

28 Pliny the Elder, Naturalis Historia, vol. xxxv, n.d., sec. 25; Zerdoun Bat-Yehuda, Les Encres Noires au Moyen-Âge (jusqu’à 1600), 81-83. 
soot, seems to be the earliest indication of inks prepared by mixing carbon pigments and metals. ${ }^{29}$ Arabic sources preserved many recipes for carbon inks transmitted in a multitude of treatises from the 1oth century on, showing that carbon inks did not lose their importance during the period studied in the present work. The Talmud dedicates many passages to the question of which inks are suitable for writing different types of documents. It is believed that the main ink mentioned in the Talmud refers to a simple carbon type.

Pure carbon inks are easily detected due to their ability to absorb light at long wavelengths. Therefore, they have traditionally been detected using simple near-infrared (NIR) photography, which entered the world of papyrology in the 193os. Today, Raman spectroscopy is the simplest way to identify this type of ink, since it is sensitive to carbon pigments.

\subsection{Plant Ink and Iron-gall Ink}

Plant ink is a solution of tannins extracted from tree bark or gallnuts.

When iron(II) is added to an extract from tree bark or gallnuts containing gallic acid, a black precipitate is formed upon oxidation in the air. This precipitate, ferrous gallate, forms the black colouring substance of the ink that is traditionally called iron-gall ink. In its generic recipe, then, iron-gall inks are produced via a reaction of the gallic acid in plant ink and soluble iron (i.e., any soluble salt of iron). If so, even an unintentional addition of iron to plant ink would result in a primitive form of iron-gall ink, ${ }^{30}$ making the unambiguous distinction between plant and iron-gall inks extremely difficult.

The majority of medieval recipes for iron-gall ink contain gallnuts as the source of gallic acid and vitriol as the source of soluble iron, the main inorganic ingredient of the ink. In medieval Latin manuscripts, vitriol ${ }^{31}$ is a mixture of hydrated metallic sulfates, containing manganese, iron, copper, zinc and other metallic sulfates in different proportions depending on the geological source of the vitriol. Though metals other than iron do not participate in

29 Dioscorides Pedanius, De Materia Medica. Being an Herbal with Many Other Medicinal Materials, Written in Greek in the First Century of the Common Era: A New Indexed Version in Modern English, trans. Tess Anne Osbaldeston and Robert P. Wood, vol. v (Johannesburg: IBIDIS, 2000), 182-83; Zerdoun Bat-Yehuda, Les Encres Noires au Moyen-Âge (jusqu'à 1600), 8 o.

30 Robert Fuchs, 'The History of Chemical Reinforcement of Texts in Manuscript: What Should We Do Now?', in Care and Conservation of Manuscripts 7: Proceedings of the Seventh International Seminar Held at the Royal Library, ed. Gillian Fellows-Jensen and Peter Springborg, vol. 7 (Care and Conservation of Manuscripts, Copenhagen: Museum Tusculanum Press, 2003), 159-70.

Karpenko and Norris, 'Vitriol in the History of Chemistry'. 
forming the ferrous gallate, the presence of these satellite impurities allows us to differentiate between different iron-gall inks.

Iron-gall inks naturally contain two phases: the reactants form a soluble phase, which easily penetrates the support; while the product corresponds to the insoluble phase, which resides on the surface. Iron-gall ink is best detected by a combination of NIR reflectography and X-ray fluorescence.

The origin and spread of iron-gall ink has not yet been properly studied. On one hand, a review of extant literary sources places the earliest Arabic recipe in the 1oth century ${ }^{32}$ and the earliest European recipe in the 12th century. ${ }^{33}$ Of note is the manuscript BL Add. 14.644, a Syriac recipe for iron-gall ink, written in both Garshuni (i.e. Arabic written with the Syriac alphabet) and Arabic. ${ }^{34}$ That manuscript, stored today in the British Library in London, has been palaeographically dated to the 9 th-1oth century, ${ }^{35}$ and the recipe would appear to be the oldest extant proper recipe for iron-gall, since it mentions all the ingredients needed for its production. On the other hand, analytic results reveal that well-defined iron-gall inks were already in use in the $3^{\text {rd }}$ or 4 th century CE. ${ }^{36}$

A predecessor of iron-gall ink, an ink containing tannins and a copper substance whose identity has not yet been completely established, can be found in

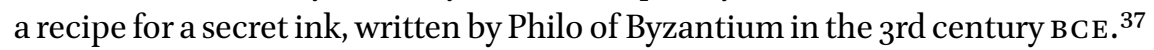
He says that a text written with tannin on leather is invisible, but becomes visible upon the addition of chalcanthum, the copper-based substance. This substance also appears in a number of earlier recipes as well as in the Talmud, albeit in a slightly different spelling. Several mentions of קנקנתום kankantum the Hebrew transcription of chalcanthum - are glossed as וידריאול - the Hebrew

32 Raggetti, 'Cum Grano Salis. Some Arabic Ink Recipes in Their Historical and Literary Context'.

33 Zerdoun Bat-Yehuda, Les Encres Noires au Moyen-Âge (jusquà 160o).

34 Alain Desreumaux et al., 'Les textes des recettes d'encres en syriaque et en garshuni', in Manuscripta syriaca: Des sources de première main, Cahiers d'études syriaques 4 (Paris: Librairie orientaliste Paul Geuthner, 2015), 195-246.

35 Alain Desreumaux, Françoise Briquel-Chatonnet, and André Binggeli, 'Un Cas Très Ancien de Garshouni ? Quelques Réflexions Sur Le Manuscrit BL Add. 14644', in Loquentes Linguis. Studi Linguistici e Orientali in Onore Di Fabrizio A. Pennacchietti, ed. Pier Giorgio Borbone, Alessandro Mengozzi, and Mauro Tosco (Wiesbaden: Harrassowitz, 20o6), 146-47.

36 Tea Ghigo et al., 'An Attempt at a Systematic Study of Inks from Coptic Manuscripts', Manuscript Cultures 11 (2018): 157-64; Aceto et al., 'The Vercelli Gospels Laid Open'.

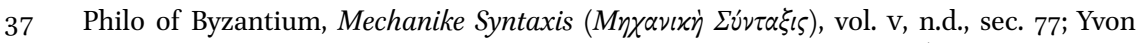
Garlan, 'Recherches de Poliorcétique Grecque, Bibliothèque Des Écoles Françaises d'Athènes et de Rome', Paris: Bibliothèque Des Écoles Françaises d'Athènes et de Rome, 1974. 
transcription of "vitriol" - in the late Middle Ages. Various references are to be found to the substance, among which are the Kiryat sefer (City of the book) written by Rabbi Menahem b. Solomon ha-Meiri (Perpignan, around 1306) ${ }^{38}$ and the commentary on the Mishnah ${ }^{39}$ by Rabbi Ovadiah b. Abraham of Bertinoro $^{40}$ (Italy c.1445-c.1515).

\subsection{Mixed Ink}

This class of ink generally contains a mixture of the previously described pure ink types - carbon ink with the addition of either iron-gall ink or plant ink. Another type of mixed ink contains carbon pigments and compounds of copper or lead of an as yet unknown chemical composition.

A mixed ink of the second type is represented by the recipe of Dioscorides from the ist century CE. He adds chalcanthum, a copper-based substance, to carbon ink to improve its preservation properties. ${ }^{41}$

Mixed inks of the first type are well attested in collections of Arabic recipes. We find several recipes in the medieval treatises written by Ibn Bādis, ${ }^{42}$ al-Marrākushī ${ }^{43}$ and al-Qalalūsīi ${ }^{44}$ In the corpus of Arabic ink recipes written between the $9^{\text {th }}$ and the 19th centuries studied by Colini in her PhD thesis, she estimated the number of mixed ink recipes at about $20 \%$ of the total corpus: $6 \%$ are carbon inks mixed with plant inks and $14 \%$ are carbon inks mixed with iron-gall inks. ${ }^{45}$

Maimonides, who lived during the 12th century, shows his extensive knowledge of the different types of ink in existence at the time, discussing their use as a function of the type of document which needs to be copied. ${ }^{46}$ Depending

38 Menahem ben Solomon Meiri, Kiryat Sefer: on the interpretation of the law, Phylacteries, and the Mezuza [Hebrew], ed. Moshe Hershler (Jerusalem: Vagshel, 1956), 32. Although I was unable to access this work, Judith Olszowy-Schlanger, 'The Making of the Bologna Scroll: Palaeography and Scribal Traditions', in The Ancient Sefer Torah of Bologna, ed. Mauro Perani, Studies in Jewish History and Culture 59 (Leiden \& Boston: Brill, 2019), 112., refers to the point of interest in this book.

39 Commentary on Mishnah Gittin 2:3 T.

40 Commonly known as "the Bartenura", in Hebrew עובדיה בן אברהם מברטנורא.

41 Dioscorides Pedanius, De Materia Medica, vol. v, secs 182-183; Zerdoun Bat-Yehuda, Les Encres Noires au Moyen-Âge (jusqu'à 16oo), 80.

42 Levey, 'Mediaeval Arabic Bookmaking and Its Relation to Early Chemistry and Pharmacology'.

43 Chabbouh, 'Two New Sources on the Art of the Mixing Ink'.

44 Chabbouh.

45 Claudia Colini et al., 'The Quest for the Mixed Inks', Manuscript Cultures 11 (2018): 41.

46 Between his Responsa and his Mishneh Torah, he mentions various types of inks, including carbon ink, iron-gall ink, and different types of mixed ink: carbon ink plus tannins, and carbon ink plus vitriol. 
on the type of document, the use of one ink or another is defended or forbidden. For example, he advises the use of a carbon ink with the addition of tannins (see more detail in section 2.4) in the case of copying a Sefer Torah, tefillin or mezuzot, in order to obtain a durable ink. On the other hand, he argues against the alleged adhesion properties of a carbon ink to which metallic salts have been added. By mentioning this, he shows that this practice existed at that time. ${ }^{47}$

Analytically, copper added to carbon-based ink was detected in five documents of the Dead Sea Scrolls, ${ }^{48}$ which seems to indicate that the ink in those documents is associated with the recipe of Dioscorides. Similar results have been obtained on four documents from the Tebtynis collection, written on papyrus during the 1 st-3rd centuries CE. ${ }^{49}$ In the Herculaneum papyri, in addition to carbon ink, lead has been detected. ${ }^{50}$ Similarly, lead in carbon ink was found in some manuscripts of the Pathyris collection, written in approximately the 2 nd-1st century BCE. ${ }^{51}$ The enigma of lead in carbon inks is yet to be solved.

\subsection{Inks in the Jewish World}

In this section, we will try to collect the known ink recipes used by Jews and compare them with the analytical results that have been reported in the research literature.

It has become customary to compare the inks used by Jews to the ones prescribed in the Talmud. Though we will also use some of the definitions from the Talmud, we would like to stress the fact that the talmudic discussion is about sacred writings and should not be automatically transferred to everyday life. With that said, we can look more closely at inks used or mentioned by Jews.

Codicological and material studies over the last decade point out the great similarity between the writing materials of Jews and their non-Jewish neighbours. ${ }^{52}$ It is interesting to compare, for example, the ink recipes offered

$47 \quad$ Maimonides, Mishneh Torah, 66.

48 Yoram Nir-El and Magen Broshi, 'The Black Ink of the Qumran Scrolls', Dead Sea Discoveries 3, no. 2 (1996): 157-67.

49 Christiansen et al., 'Chemical Characterization of Black and Red Inks Inscribed on Ancient Egyptian Papyri'.

50 Brun et al., 'Revealing Metallic Ink in Herculaneum Papyri'.

$5^{1}$ Christiansen et al., 'Chemical Characterization of Black and Red Inks Inscribed on Ancient Egyptian Papyri'.

$5^{2}$ Rabin, Hahn, and Binetti, 'Inks used in medieval Hebrew manuscripts: a typological study'; Malachi Beit-Arié, Hebrew Codicology. Historical and Comparative Typology of Hebrew Medieval Codices Based on the Documentation of the Extant Dated Manuscripts Using a Quantitative Approach, ed. Nurit Pasternak and Ilana Goldberg, Preprint Internet 
by Maimonides - who lived in 12th-century Egypt - to the ink allegedly used by Rashi ${ }^{53}$ - who lived in northern France in the 11th century; we could take these two as representative of ink users in the Sephardic and Ashkenazic worlds, respectively. Maimonides - who could choose from a variety of inks since in 12th-century Egypt carbon, iron-gall, plant and different types of mixed inks are well known - decides on using a specific type of mixed ink, carbon ink with the addition of tannins. ${ }^{54}$ His seemingly clear statement is based on the discussion in the Talmud, Mishnah Sotah 2:4, ${ }^{55}$ concerning the obligation to erase text that has been written. Since iron-gall ink is difficult to erase, he is against its use. In contrast, the case of Rashi is more difficult to determine because he did not leave an ink recipe. Monique Zerdoun has tried to trace the ink that Rashi was using, based on an analysis of his commentaries on the Talmud. ${ }^{56}$ Reading Rashi's commentaries on the tractate Shabbat 23a:5, ${ }^{57}$ she concluded that he did not know carbon ink except for what he read in Babylonian geonic responsa, ${ }^{58}$ and this would also exclude a large number of the mixed inks presented above. Therefore, she concluded he was using either iron-gall inks or plant inks. From there, using the Tosafot on the tractate Gittin 19a:659 - which says that adding crushed kankantum to the ink turns it black - she suggested that he was probably familiar only with plant inks. Indeed, if adding kankantum to what is already an ink changes its colour, then the ink itself must be a plant ink. At present, for as long as there is no autographic evidence from Rashi, we can neither confirm Zerdoun's deductions nor compare them with analytical observations.

It is difficult to assess the differences between the day-to-day life of Jews who belonged to different rabbinic and non-rabbinic communities. As mentioned above, the Talmud, the source for laws regulating the life of a "rabbinic" Jew, comments on inks. Where it does this, it does not give recipes per se, but rather conversations between rabbis and suggestions, which are then later

English version 0.2 (Israel Academy of Sciences and Humanities, 2018), https://web.nli .org.il/sites/NLI/English/collections/manuscripts/hebrewcodicology/Documents/Hebrew -Codicology-continuously-updated-online-version-ENG.pdf.

53 Hebrew: רשי

54 Maimonides, Mishneh Torah.

55 https://www.sefaria.org/Mishnah_Sotah.2.4?ven=Sefaria_Community_Translation\& lang=bi.

56 Zerdoun Bat-Yehuda, Les Encres Noires au Moyen-Âge (jusqu'à 16oo), 103, 117-19.

57 https://www.sefaria.org/Rashi_on_Shabbat.23a.5.1?lang=en\&with=all\&lang2=en.

58 Zerdoun Bat-Yehuda, Les Encres Noires au Moyen-Âge (jusqu'à 160o), 117. quoting Rashi's commentaries on Talmud Bavli Shabbat 23a:6. https://www.sefaria.org/Tosafot_on_Gittin.19a.6.2?lang=bi\&with=all\&lang2=en. 
commented on by Jewish scholars. In the previous example, we saw that while Rashi did not use carbon ink in his everyday life, he knew about it through the study of a Jewish text. On the other hand, in Talmud Bavli Eruvin 13a:8-12, we find a story about Rabbi Meïr, a student of Rabbi Akiva, who speaks of how additives to inks affect their properties: we learn that Rabbi Meir knew that by adding a particular substance, kankantum, he could improve the adherence of the ink. From this story, we deduce that Rabbi Meïr was preparing his ink himself, and that it was a mixed ink that contained carbon and a metallic salt. ${ }^{60}$

When it comes to analytical observations made on Hebrew documents, very little has been done thus far. Analyses made on the Dead Sea Scrolls, ${ }^{61}$ mentioned in section II.2.3 about mixed inks, have shown the use of both carbon ink and a single type of mixed ink. ${ }^{62}$ In contrast, most analyses conducted on Hebrew codices have shown that iron-gall inks were used in many codices, both European and Oriental: for example, in the Oppenheimer Siddur, an illuminated ${ }_{15}$ th-century Askenazic book; ${ }^{63}$ in Codex Hebraicus 205, written on parchment in 14th-15th century Spain; in Codex Levy 148, a 17th century book from Kurdistan; in Codex Levy 102, written on paper during the 17th century in Yemen; ${ }^{64}$ in the giant Erfurt Bible; $; 5$ and in Codex Hebraicus 18 and Codex Hebraicus $53{ }^{66}$ both written on parchment by the same scribe during the 15 th century. A summary of these documents is given in Table 2.1.

6o It is necessary to remind the reader that the word kankantum changed its meaning from copper sulfate to iron sulfate at some point in the early Middle Ages.

61 This information is based on only a small number of the Dead Sea Scrolls that have been studied using the XRF method to detect metals.

62 Nir-El and Broshi, 'The Black Ink of the Qumran Scrolls'.

63 Suzanne Wijsman et al., 'Uncovering the Oppenheimer Siddur: Using Scientific Analysis to Reveal the Production Process of a Medieval Illuminated Hebrew Manuscript', Heritage Science 6, no. 1 (2018): 1-15, https://doi.org/10.1186/s40494-o18-o179-o.

64 Rabin, Hahn, and Binetti, 'Inks used in medieval Hebrew manuscripts: a typological study'.

65 Oliver Hahn et al., 'The Erfurt Hebrew Giant Bible and the Experimental XrF Analysis of Ink and Plummet Composition', Gazette Du Livre Médiéval 51, no. 1 (2007): 16-29, https:// doi.org/10.3406/galim.2007.1754.

66 Gottfried Reeg, 'Codex Hebraicus 18 and Codex Hebraicus 53 in the Hamburg State and University Library - "Corrected by Yiṣhaq of Arles", in Jewish Manuscript Cultures: New Perspectives, ed. Irina Wandrey, Studies in Manuscript Cultures 13 (Berlin \& Boston: Walter de Gruyter, 2017), 363-420, https://doi.org/10.1515/9783110546422-015. 
TABLE 2.1 Summary of the analytical observations conducted on Hebrew documents

\begin{tabular}{|c|c|c|c|c|}
\hline Document & Date & Support & Place & Type of ink \\
\hline Dead Sea Scrolls & $\begin{array}{l}\text { 3rd century ВСЕ- } \\
\text { 1st century CE }\end{array}$ & $\begin{array}{l}\text { Light parchment, } \\
\text { brown parchment } \\
\text { and leather }\end{array}$ & $\begin{array}{l}\text { Found in } \\
\text { the Judean } \\
\text { desert }\end{array}$ & $\begin{array}{l}\text { Carbon ink; } \\
\text { carbon ink } \\
+\mathrm{Cu}\end{array}$ \\
\hline $\begin{array}{l}\text { Prato Haggadah } \\
\text { (MS 9478) }\end{array}$ & 1300 & Parchment & Spain & $\begin{array}{l}\text { Iron-gall ink } \\
\text { for the text; } \\
\text { carbon ink for } \\
\text { illumination }\end{array}$ \\
\hline Erfurt Bible & 14th century & Parchment & $\begin{array}{l}\text { German } \\
\text { Ashkenazic }\end{array}$ & Iron-gall ink \\
\hline $\begin{array}{l}\text { Codex Hebraicus } \\
205\end{array}$ & $14^{\text {th }}-15^{\text {th }}$ century & Parchment & Spain & Iron-gall ink \\
\hline $\begin{array}{l}\text { Codex Hebraicus } \\
53\end{array}$ & 1410 & Parchment & Italy, Perugia & Iron-gall ink \\
\hline $\begin{array}{l}\text { Codex Hebraicus } \\
18\end{array}$ & 1416 & Parchment & Italy & Iron-gall ink \\
\hline $\begin{array}{l}\text { Oppenheimer } \\
\text { Siddur }\end{array}$ & 1471 & Parchment & $\begin{array}{l}\text { Askenazic, } \\
\text { Rhine region }\end{array}$ & Iron-gall ink \\
\hline Codex Levy 148 & 17th century & Paper & Kurdistan & Iron-gall ink \\
\hline Codex Levy 102 & 17th century & Paper & Yemen & Iron-gall ink \\
\hline
\end{tabular}

Finally, it is important to reiterate that, strictly speaking, the religious limitations in the use of inks relates only to sacred manuscripts. Therefore, no correlations should be made between the talmudic prescription and the use of inks in the medieval codices. We plan a detailed study of religious Hebrew documents that will hopefully reveal whether such a correspondence exists within those specific documents.

\subsection{Inks in the Cairo Genizah}

While black writing ink is undoubtedly the most common type of ink used in the Cairo Genizah (though it may now be brown following deterioration), it is worth mentioning that coloured inks were also in use. Red inks seem to have been the most common non-black ink in the Genizah, and were used for a number of different purposes: to write a document (e.g. T-S K5.85, Or.1080 1.63, T-S NS 159.183 and T-S 16.73); to decorate a document (e.g. T-S K6.163); or as vocalisation enhancement (e.g. T-S Ar.42.1, T-S AS 107.66 and T-S AS 155.65). Other colours have also been used in different documents for writing, illuminations, 
vocalisations and contouring: for example, green (e.g. T-S K5.2 and T-S 16.113), gold (e.g. T-S K5.13 and T-S 16.107), blue (e.g. T-S 16.106) and purple (e.g. T-S AS 162.57). In this study, however, only documents written in black ink were investigated.

Using examples found in the Cairo Genizah, Goitein claims that ink was usually not prepared by the scribe but by a specialist. ${ }^{67}$ To substantiate his claim, he used manuscript T-S 13J10.5, where a scribe from Sahrajt, in Egypt, asks someone in Cairo to fill an empty inkwell with a good quality ink because the one he bought before, also in Cairo, was of no use. Goitein notes as well that in manuscript T-S 8.86, a scribe writes to his father that, since the ink he was using was not good, it was necessary to prepare a new batch or to buy fresh ink. ${ }^{68}$ Based on this document, it would seem that there were two options: preparing the ink oneself or buying it from an ink manufacturer.

Five recipes for black inks have been found in the Genizah so far; ${ }^{69}$ these are given in Table 2.2. Two of the manuscripts containing these recipes are stored in the CUL, while the remaining recipes have been graciously shared with me by Ashur. ${ }^{70}$ None of these manuscripts is dated, and only two of them ENA 3370.4 and ENA 3381.4 - are written in Judeo-Arabic, while the remaining manuscripts are written in Arabic.

TABLE 2.2 Manuscripts containing ink recipes that have been found in the Genizah, together with their description

\begin{tabular}{|c|c|c|c|c|}
\hline Classmark & Support & Language & Ingredients $^{\mathrm{a}}$ & Ink type \\
\hline ENA 3381.4 & Paper & Judeo-Arabic & & \\
\hline ENA 3370.4 & Paper & Judeo-Arabic & Gum arabic, vitriol & Iron-gall ink \\
\hline ENA 3960.5 & Paper & Arabic & Vinegar, vitriol, honey & Iron-gall ink \\
\hline T-S Ar.4o.64 & Paper & Arabic & $\begin{array}{l}\text { Gallnuts, gum arabic, } \\
\text { wine of Tabas }\end{array}$ & Plant ink \\
\hline T-S Ar.39.199 & Paper & Arabic & $\begin{array}{l}\text { Gum arabic, mulberry } \\
\text { tree, vitriol }\end{array}$ & Iron-gall ink \\
\hline
\end{tabular}

a Identification of the elements for all these recipes has been made by Wissem Gueddich.

67 Goitein, A Mediterranean Society: The Community, 233-34.

68 Goitein, 574.

69 Ink recipes for colours other than black have also been found in the Genizah. For example, Mosseri I.122.1 (formely called Med 15) gives a recipe for red ink or golden ink, and there is a similar recipe in T-S Ar.39.199. In ENA 3960.5, the preparation of other coloured inks is described: blue, red, green, argent and golden inks.

70 I am grateful to Amir Ashur for bringing these manuscripts to my attention and to Wissem Gueddich for translating them to me. 


\subsection{Limits of Material Analysis}

As was explained very clearly by Colini in her $\mathrm{PhD}$ thesis, the role of ink recipes has not yet been sufficiently studied, ${ }^{71}$ although recently a number of different studies have been conducted to examine how accurate medieval recipes are. ${ }^{72}$

The role of the recipe needs to be clarified in every case since it is most probably not constant but rather dependent on the document to be written with the ink. However, it is important to stress that ink formulations are usually not very different from one another; or at least, they are sufficiently similar to mask any chance of correlating between a formulation and a recipe. For us, then, the main possible way of differentiating between specific iron-gall inks is to record and compare their fingerprints - not looking for markers of a specific recipe but rather for markers of a specific vitriol, that is, markers of a specific source of metallic sulfates. The specific vitriol is, incidentally, only rarely mentioned in the ink recipes. Using only non-invasive protocols, it is practically impossible to attribute the ink under investigation to a specific formulation of a recipe, and any declaration to the contrary is, in our opinion, false. Thus in Table 2.3 below, which gives examples of the extant recipes and the corresponding analytical results, we refer only to the ink types.

71 Colini, 'From Recipes to Material Analysis the Arabic Tradition of Black Inks and Paper Coatings (9th-20th Century)', 132-37.

72 Rafael Javier Díaz Hidalgo et al., 'New Insights into Iron-Gall Inks through the Use of Historically Accurate Reconstructions', Heritage Science 6, no. 63 (2018): 1-15, https:// doi.org/10.1186/s40494-018-0228-8; Colini, 'From Recipes to Material Analysis the Arabic Tradition of Black Inks and Paper Coatings (9th-2oth Century)'; Fani, 'Le arti del libro secondo le fonti arabe originali. I ricettari arabi per la fabbricazione degli inchiostri (sec. IX-XIII)'; Martin Levey, 'Some Black Inks in Early Mediaeval Jewish Literature', Chymia 9 (1964): 27-31; Abarrou, L'art du livre et sa fabrication au XI ${ }^{e}$ siècle; Alkin Lewis, 'The Lachish Letters and the Use of Iron Inks in Antiquity', Nature 139 (1937): 470-470; Lucas, 'The Inks of Ancient and Modern Egypt'; Schopen, Tinten und Tuschen des arabisch-islamischen Mittelalters; Zekrgoo, 'Methods of Creating, Testing and Identifying Traditional Black Persian Inks'; Raggetti, 'Cum Grano Salis. Some Arabic Ink Recipes in Their Historical and Literary Context'; Michaelle Biddle, 'Inks in the Islamic Manuscripts of Northern Nigeria: Old Recipes, Modern Analysis and Medicine',Journal of Islamic Manuscripts 2, no. 1 (2011): 1-35, https://doi.org/10.1163/187846411X566869. 
TABLE 2.3 Examples of extant recipes and the corresponding analytical results

Literary sources - Recipes Analytically confirmed

\begin{tabular}{|c|c|c|c|c|c|c|}
\hline \multirow[t]{3}{*}{$\begin{array}{l}\text { Carbon } \\
\text { ink }\end{array}$} & $\begin{array}{l}\text { Pliny } \\
\text { Vitruvius }\end{array}$ & $\begin{array}{l}\text { ist century } \\
\text { 1st century } \\
\text { BCE }\end{array}$ & $\begin{array}{l}\text { Roman empire }^{\mathrm{a}} \\
\text { Roman empire }^{\mathrm{b}}\end{array}$ & & Antiquity & \\
\hline & Ibn Bādis & 1025 & Morocco $^{c}$ & & $7_{\text {th-12th }}$ & Middle East \\
\hline & Maimonides & 12th century & Egypt $^{\mathrm{d}}$ & & century & \\
\hline \multirow[t]{5}{*}{$\begin{array}{l}\text { Iron-gall } \\
\text { ink }\end{array}$} & $\begin{array}{l}\text { Papyrus v of } \\
\text { Leyden }\end{array}$ & 3 rd century & Greek $^{\mathrm{e}}$ & $\begin{array}{l}\text { Ms Berol. } \\
\text { Orient. Oct. } \\
987\end{array}$ & $\begin{array}{l}3^{\text {rd- }}-4 \text { th } \\
\text { century }\end{array}$ & Egypt (Coptic) $)^{\mathrm{f}}$ \\
\hline & $\begin{array}{l}\text { BL Add. } \\
14.644\end{array}$ & 9th century & Syriacg $^{g}$ & $\begin{array}{l}\text { Vercelli } \\
\text { Gospels }\end{array}$ & 4th century & Northern Italyh \\
\hline & Al-Razi & $925-935$ & Iran & Island codices & 9th century & Ireland-UK ${ }^{\mathrm{i}}$ \\
\hline & Ibn Bādis & 1025 & Morocco & & & \\
\hline & Theophilusi & $\begin{array}{l}\text { 12th century } \\
\mathrm{CE}\end{array}$ & Germanyk & & & \\
\hline
\end{tabular}

a Pliny the Elder, Naturalis Historia, vol. xxxv, sec. 25; Zerdoun Bat-Yehuda, Les Encres Noires au Moyen-Âge (jusqu'à 16oo), 81-83.

b Vitruvius, De Architectura, vol. viI, n.d., sec. 10.

c Levey, 'Mediaeval Arabic Bookmaking and Its Relation to Early Chemistry and Pharmacology'.

d Zerdoun Bat-Yehuda, Les Encres Noires au Moyen-Âge (jusqu'à 160o), 124-126; Schopen, Tinten und Tuschen des arabisch-islamischen Mittelalters, 141-144.

e An edition of this text is apparently available in Karl Preisendanz, Papyri Graecae Magicae. Die Griechischen Zauberpapyri, Herausgegeben Und Übersetzt von Karl Preisendanz. V. 2 (Berlin: Teubner, 1931), 83. Unfortunately, however, I was unable to access this work, and rely on Zerdoun Bat-Yehuda, Les Encres Noires au Moyen-Âge (jusqu’à 1600$)$, 94.

f Ghigo et al., 'An Attempt at a Systematic Study of Inks from Coptic Manuscripts'.

g Desreumaux et al., 'Les textes des recettes d'encres en syriaque et en garshuni'.

h Aceto et al., 'The Vercelli Gospels Laid Open'.

i Susan Bioletti et al., 'The Examination of the Book of Kells Using Micro-Raman Spectroscopy', Journal of Raman Spectroscopy 40, no. 8 (2009): 1043-49, https://doi.org/10.1002/jrs.2231; Lucia Burgio, Susan Bioletti, and Bernard Mehan, 'Non-Destructive, in Situ Analysis of Three Early Medieval Manuscripts from Trinity College Library Dublin (Codex Usserianus Primus, Book of Durrow, Book of Armagh)', in Making Histories: Proceedings of the Sixth International Conference on Insular Art, York 2011, ed. Jane Hawkes (Making Histories: Sixth International Conference on Insular Art, York, 2013), 42-49; Katherine L. Brown and Robin J. H. Clark, 'The Lindisfarne Gospels and Two Other 8th Century Anglo-Saxon/Insular Manuscripts: Pigment Identification by Raman Microscopy', Journal of Raman Spectroscopy 35, no. 1 (2004): 4-12, https://doi.org/10.1002/jrs.1110.

j Although according to Zerdoun, Theophilus' recipe is an iron-gall ink, in our interpretation this is a plant ink as the primary product is only a plant ink: the addition of atramentum or of iron is secondary. Zerdoun Bat-Yehuda, Les Encres Noires au Moyen-Âge (jusqu'à 16oo), 153-65.

k Presbiter Theophilus, De Diversis Artibus., vol. I, n.d., sec. 40. 
TABLE 2.3 Examples of extant recipes and the corresponding analytical results (cont.)

\begin{tabular}{|c|c|c|c|c|c|c|c|c|}
\hline & \multicolumn{4}{|c|}{ Literary sources - Recipes } & \multicolumn{4}{|c|}{ Analytically confirmed } \\
\hline \multirow[t]{3}{*}{ Plant ink } & \multirow{3}{*}{$\begin{array}{l}\text { Martinus } \\
\text { Capella } \\
\text { Rashi? }\end{array}$} & \multirow[t]{2}{*}{$5^{\text {th century }}$} & \multicolumn{2}{|l|}{ Cartages $^{1}$} & \multirow{3}{*}{$\begin{array}{l}\text { Stuttgarter } \\
\text { Psalter }\end{array}$} & \multirow[t]{3}{*}{$9^{\text {th }}$ century } & \multirow{3}{*}{\multicolumn{2}{|c|}{ Unknown ${ }^{\mathrm{m}}$}} \\
\hline & & & & & & & & \\
\hline & & 11th century & $\begin{array}{l}\text { Northern } \\
\text { Troyes }\end{array}$ & France, & & & & \\
\hline \multirow[t]{4}{*}{$\begin{array}{l}\text { Mixed } \\
\text { ink }\end{array}$} & Dioscorides & 1st century & $\begin{array}{l}\text { Roman } \\
\text { empire }^{\mathrm{n}}\end{array}$ & $\mathrm{CI}+\mathrm{Cu}$ & $\begin{array}{l}\text { Dead Sea } \\
\text { Scrolls }\end{array}$ & 1st century & $\begin{array}{l}\text { Found } \\
\text { in the } \\
\text { Judean } \\
\text { desert }^{\circ}\end{array}$ & $\mathrm{CI}+\mathrm{Cu}$ \\
\hline & Rabbi Meïr & $\begin{array}{l}\text { 1st-2nd } \\
\text { century }\end{array}$ & $\begin{array}{l}\text { Land of } \\
\text { Israelp }\end{array}$ & $\begin{array}{l}\mathrm{CI}+ \\
\text { copper- } \\
\text { based } \\
\text { substance }\end{array}$ & $\begin{array}{l}\text { Tebtynis } \\
\text { collection }\end{array}$ & $\begin{array}{l}\text { 1st-3rd } \\
\text { century }\end{array}$ & $\begin{array}{l}\text { Found } \\
\text { in Egypt, } \\
\text { Fayyumq }\end{array}$ & $\mathrm{CI}+\mathrm{Cu}$ \\
\hline & Maimonides & 12th century & Egypt $^{r}$ & $\begin{array}{l}\mathrm{CI}+ \\
\text { tannins }\end{array}$ & $\begin{array}{l}\text { Herculaneum } \\
\text { papyri }\end{array}$ & $\begin{array}{l}\text { 3rd century } \\
\text { BCE-1st }\end{array}$ & $\begin{array}{l}\text { Found } \\
\text { in Italy, }\end{array}$ & $\mathrm{CI}+\mathrm{Pb}$ \\
\hline & Ibn Bādis & 1025 & Morocco & $\begin{array}{l}\text { CI + iron- } \\
\text { gall ink }\end{array}$ & & century CE & $\begin{array}{l}\text { Hercula- } \\
\text { neum }\end{array}$ & \\
\hline Other & $\begin{array}{l}\text { Philo of } \\
\text { Byzantium }\end{array}$ & $\begin{array}{l}\text { 3rd century } \\
\text { BCE }\end{array}$ & Greece $^{t}$ & $\begin{array}{l}\text { invisible } \\
\text { ink, prob- } \\
\text { ably a } \\
\text { predeces- } \\
\text { sor of } \\
\text { iron-gall } \\
\text { ink }\end{array}$ & $\begin{array}{l}\text { Bilingual } \\
\text { papyri stored } \\
\text { in the Louvre } \\
\text { collection }\end{array}$ & $\begin{array}{l}\text { 3rd-2nd } \\
\text { century } \\
\text { BCE }\end{array}$ & u & \\
\hline
\end{tabular}

Note: CI refers to a carbon ink.

1 Martianus Capellae, De Nuptiis Philologiae et Mercurii, vol. III, n.d., sec. 225, https://ia8o2708.us.archive .org/1/items/denuptiisphilolooomartuoft/denuptiisphilolooomartuoft.pdf.

m Oliver Hahn, 'Die Farben und Tinten im Stuttgarter Psalter-Naturwissenschaftliche Untersuchungen', in Kupfergrün, Zinnober \& Co. - Der Stuttgarter Psalter, ed. Vera Trost, Andrea Pataki-Hundt, and Enke Huhsmann (Stuttgart: Württembergische Landesbibliothek, 2011), 111-21.

n Dioscorides Pedanius, De Materia Medica, vol. v, secs 182-183; Zerdoun Bat-Yehuda, Les Encres Noires au Moyen-Âge (jusqu'à 1600), 80.

o Nir-El and Broshi, 'The Black Ink of the Qumran Scrolls'; Solomon H. Steckoll, 'Investigations of the Inks Used in Writing the Dead Sea Scrolls', Nature 220, no. 5162 (October 1968): 91-92, https://doi. org/10.1038/220091bo.

p Talmud Bavli, Eruv in 13a:8-12; Zerdoun Bat-Yehuda, Les Encres Noires au Moyen-Âge (jusqu'à 160o), 105-7.

q Christiansen et al., 'Chemical Characterization of Black and Red Inks Inscribed on Ancient Egyptian Papyri'.

r Maimonides, Mishneh Torah.

s Brun et al., 'Revealing Metallic Ink in Herculaneum Papyri'.

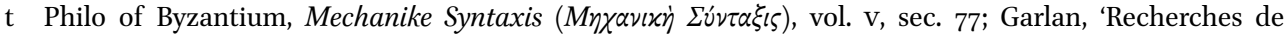
Poliorcétique Grecque, Bibliothèque Des Écoles Françaises d'Athènes et de Rome', 324.

u Elisabeth Delange et al., 'Apparition de l'encre métallogallique en Égypte à partir de la collection de papyrus du Louvre', Revue d'Égyptologie 41 (1990): 213-17. 